\title{
KONTRIBUSI PEMBANGUNAN INFRASTRUKTUR PANEN AIR TERHADAP PENINGKATAN PENDAPATAN DAN KESEJAHTERAAN PETANI
}

\author{
Popi Rejekiningrum ${ }^{1, *}$ dan Budi Kartiwa ${ }^{1}$ \\ ${ }^{1}$ Balai Penelitian Agroklimat dan Hidrologi, Badan Penelitian dan Pengembangan Pertanian, \\ Kementerian Pertanian \\ Telp. (251) 8312760, Fax. (0251) 8323909, Hp. 08128027623 \\ * Email: popirejeki@gmail.com
}

\section{RINGKASAN}

Pembangunan infrastruktur panen air (embung dan bangunan air lainnya) merupakan upaya mengatasi permasalahan penyediaan air irigasi di lahan pertanian di Indonesia. Sesuai Direktif Presiden RI pada acara Rakernas Pembangunan Pertanian di Hotel Bidakara, Jakarta tanggal 5 Januari 2017 dan Pekan Nasional Petani Nelayan ke-15, di Aceh tanggal 6 Mei 2017, Presiden mengamanatkan untuk membangun embung dan penampung air lainnya sebanyak 30.000 unit. Direktif tersebut ditindaklanjuti dengan rencana diterbitkannya Inpres tentang percepatan pembangunan embung kecil dan bangunan penampung air lainnya tahun 2017. Pembangunan ditujukan untuk tanaman padi sangat bermanfaat dan menguntungkan karena tidak membutuhkan investasi besar. Pembangunan infrastruktur panen air dengan layanan seluas 4 juta ha akan diperoleh keuntungan kotor Rp 81,7 T, sehingga pendapatan bersih mencapai Rp. 59,1 T. Tanaman jagung diperoleh keuntungan kotor Rp 72,96 T dan pendapatan bersih mencapai Rp. 50,37 T. Demikian pula manfaatnya untuk bawang merah akan menghasilkan penerimaan kotor sebesar Rp. 324,25 T sehingga pendapatan bersih mencapai Rp. 301,67 T.

Kata Kunci: infrastruktur panen air, air irigasi, lahan pertanian, kesejahteraan petani

\section{PERNYATAAN KUNCI}

- Total lahan pertanian seluas 62,5 juta ha, didominasi oleh topografi bergelombang hingga berbukit sekitar 33,86 juta hektar (54\%). Kebijakan nasional infrastruktur panen air hingga saat ini melalui pembangunan bendung tertuju terhadap 3,08 juta ha (5\%) lahan datar untuk sawah irigasi teknis. Dengan demikian terdapat potensi pengembangan infrastruktur irigasi embung dan bangunan air lainnya yang lebih luas, yaitu 33,86 juta ha (54\%) lahan kering bergelombang hingga berbukit dan sawah tadah hujan serta irigasi sederhana 3 juta ha dengan topografi datar.

- Pembangunan embung kecil dan bangunan penampung air lainnya dilakukan dengan memanfaatkan air hujan yang mengalir di sungai-sungai, terutama di wilayah bergelombang 
hingga berbukit dengan menerapkan konsep panen air bertingkat (cascade water harvesting). Untuk daerah datar embung dan long storage dibangun untuk menampung air saat musim hujan dan digunakan sebagai air irigasi pada musim kemarau.

- Pembangunan infrastruktur panen air dan pemeliharaannya perlu segera diimplementasikan agar produksi pangan nasional meningkat dan target swasembada pangan dapat dipertahankan. Untuk mencapai keberhasilan tersebut, diperlukan pengawalan dan pendampingan dalam pembangunan infrastruktur panen air agar kualitasnya baik, posisinya tepat, dan dapat terlaksana tepat waktu.

\section{REKOMENDASI KEBIJAKAN}

- Pengembangan embung kecil dan bangunan penampung air lainnya memiliki keunggulan dibandingkan dengan pembangunan bendung besar, antara lain: biaya investasi rendah (melibatkan partisipasi masyarakat), waktu pemanfaatan untuk irigasi relatif cepat (quick yields), pemeliharaan relatif murah, tidak memiliki risiko sosial tinggi (pembebasan lahan), ramah lingkungan, dan memiliki co-benefit tinggi (perikanan, agrowisata, konservasi air dll).।
- Biaya satuan pembangunan embung dan bangunan air lainnya jauh lebih murah dibandingkan dengan biaya satuan bendung, yaitu berturut-turut Rp. 4 juta/ha dan Rp 157 juta/ha. Dengan biaya investasi Rp. 73,3 T dapat dibangun embung dan bangunan air lainnya dengan total luas layanan mencapai 18,4 juta ha, sedangkan untuk pembangunan bendung hanya mampu melayani lahan seluas 468,4 ribu ha.

- Pembangunan embung kecil dan bangunan penampung air lainnya untuk tanaman padi sangat bermanfaat dan menguntungkan karena tidak membutuhkan investasi besar. Pembangunan infrastruktur panen air ini dengan layanan seluas 4 juta ha akan diperoleh keuntungan kotor $\mathrm{Rp} 81,7 \mathrm{~T}$, sehingga pendapatan bersih mencapai Rp. 59,1 T, sedangkan untuk tanaman jagung diperoleh keuntungan kotor Rp 72,96 $\mathrm{T}$ dan pendapatan bersih mencapai Rp. 50,37 T. Demikian pula manfaatnya untuk bawang merah akan menghasilkan penerimaan kotor sebesar Rp 324,25 T sehingga pendapatan bersih mencapai Rp. 301,67 T. 


\section{PENDAHULUAN}

Potensi sumber daya air di Indonesia adalah sebesar 3.906 .500 juta $\mathrm{m}^{3} /$ tahun. Dari total potensi tersebut yang dapat dimanfaatkan sebesar 691.300 juta $\mathrm{m}^{3} /$ tahun atau sekitar $18 \%$ dari total potensi yang ada. Dari total yang dapat dimanfaatkan, kapasitas yang sudah terpasang sebesar 175.100 juta $\mathrm{m}^{3} /$ tahun $(25,3 \%)$ dan sebesar 516.200 juta $\mathrm{m}^{3} /$ tahun masih belum terpasang. Pemanfaatan air di Indonesia dibagi menjadi 2 yaitu pemanfaatan dari sisi Domestic Municipal Industry (DMI) dan sumber irigasi. Pemanfaatan untuk DMI sebesar 34.100 juta $\mathrm{m}^{3} /$ tahun $(19,5 \%)$, sedangkan untuk irigasi sebesar 141.000 juta $\mathrm{m}^{3} /$ tahun (80,5\%) (Puslitbang SDA, 2016 dan Bappenas, 2010). Keterbatasan potensi sumberdaya air dan kompetisi penggunaan air untuk berbagai sektor menjadi masalah utama penyediaan air irigasi di lahan pertanian di Indonesia.

Kebijakan nasional dalam penyediaan air irigasi saat ini dilakukan dengan pembangunan bendung dan bendungan yang hanya mampu mengairi 3,08 juta ha ( $5 \%$ dari lahan pertanian seluas 62,5 juta ha) lahan datar untuk sawah irigasi teknis. Namun demikian biaya yang diperlukan untuk membangun bendung sangat mahal dan untuk dapat dimanfaatkan secara langsung memerlukan waktu yang relatif lama. Sementara itu terdapat potensi lahan pertanian bergelombang-berbukit seluas 33,86 juta ha $(54 \%)$ dan lahan pertanian datar lainnya seluas 25,54 juta ha (41\%) yang dapat dikembangkan melalui pembangunan embung kecil dan bangunan penampung air lainnya yang relatif lebih murah dan dapat segera dimanfaatkan untuk pertanian.

Dalam upaya mengatasi permasalahan penyediaan air irigasi di lahan pertanian di Indonesia Presiden Joko Widodo mengeluarkan Direktif Presiden RI untuk membangun embung/bangunan air lainnya 2017 sebanyak 30.000 unit pada acara Rakernas Pembangunan Pertanian di Hotel Bidakara, Jakarta tanggal 5 Januari 2017 dan Pekan Nasional Petani Nelayan ke-15, di Aceh tanggal 6 Mei 2017. Direktif tersebut ditindaklanjuti dengan terbitnya Inpres tentang percepatan pembangunan embung kecil dan bangunan penampung air lainnya tahun 2017.

Pengembangan embung kecil dan bangunan penampung lainnya memiliki keunggulan dibandingkan dengan pembangunan bendung besar, antara lain: biaya investasi rendah (melibatkan partisipasi masyarakat), waktu pemanfaatan untuk irigasi relatif cepat (quick yields), pemeliharaan relatif murah, tidak memiliki risiko sosial tinggi (pembebasan lahan), ramah lingkungan, dan memiliki co-benefit tinggi (perikanan, agrowisata, konservasi air dll). 
Tujuan kegiatan adalah: (1) Menghitung biaya pembangunan embung kecil dan bangunan penampung air lainnya dibandingkan dengan bendung,

Menghitung keuntungan pembangunan embung kecil dan bangunan penampung air lainnya untuk tanaman padi jagung, dan bawang merah, dan (3) Menghitung keuntungan pembangunan infrastruktur panen air (embung kecil dan bangunan air lainnya) dibandingkan bendung.

\section{Potensi Luas Lahan}

Saat ini Indonesia mempunyai luas lahan pertanian baku sekitar 62,5 juta ha.

Tabel 1. Sebaran lahan pertanian menurut topografi wilayah

\begin{tabular}{lccccc}
\hline \multicolumn{1}{c}{ Penggunaan Lahan } & $\begin{array}{c}\text { Luas Baku } \\
\text { (Juta ha) }\end{array}$ & \multicolumn{2}{c}{ Datar } & \multicolumn{2}{c}{ Bergelombang-Berbukit } \\
\cline { 3 - 6 } & & (Juta ha) & $(\%)$ & (Juta ha) & $(\%)$ \\
Sawah & 8,1 & 3,08 & 38 & 5,02 & 62 \\
Tegal/Kebun & 12,01 & 4,80 & 40 & 7,21 & 60 \\
Ladang/Huma & 5,02 & 1,41 & 28 & 3,61 & 72 \\
Lahan Tidur & 11,68 & 3,50 & 30 & 8,18 & 70 \\
Lahan Perkebunan & 23,48 & 15,26 & 65 & 8,22 & 35 \\
Ladang Pengembalaan & 2,19 & 0,57 & 26 & 1,62 & 74 \\
(hijauan pakan ternak) & & & & & \\
Total & 62,5 & 28,62 & 46 & 33,86 & 54 \\
\hline
\end{tabular}

Sumber: BBSDLP (2016a), unpublished data

Kebijakan nasional infrastruktur panen air hingga saat ini melalui pembangunan bendung dan bendungan ditujukan untuk 3,08 juta ha (5\% dari lahan pertanian) lahan datar untuk sawah irigasi teknis. Sementara itu terdapat potensi pengembangan infrastruktur panen air
Lahan pertanian ini dibedakan menjadi 6 tipe penggunaan lahan: sawah 8,1 juta ha, tegal/kebun 12,01 juta ha, ladang/huma 5,02 juta ha, lahan tidur 11,68 juta ha, perkebunan 23,48 juta ha, dan ladang penggembalaan 2,19 juta ha. Secara topografis, lahan pertanian baku ini didominasi oleh lahan bertopografi bergelombang hingga berbukit, yang meliputi areal 33,86 juta hektar atau 54\% dari luas total lahan pertanian (Tabel 1). Sisanya seluas 28,62 juta ha atau $46 \%$ berada pada lahan datar. 

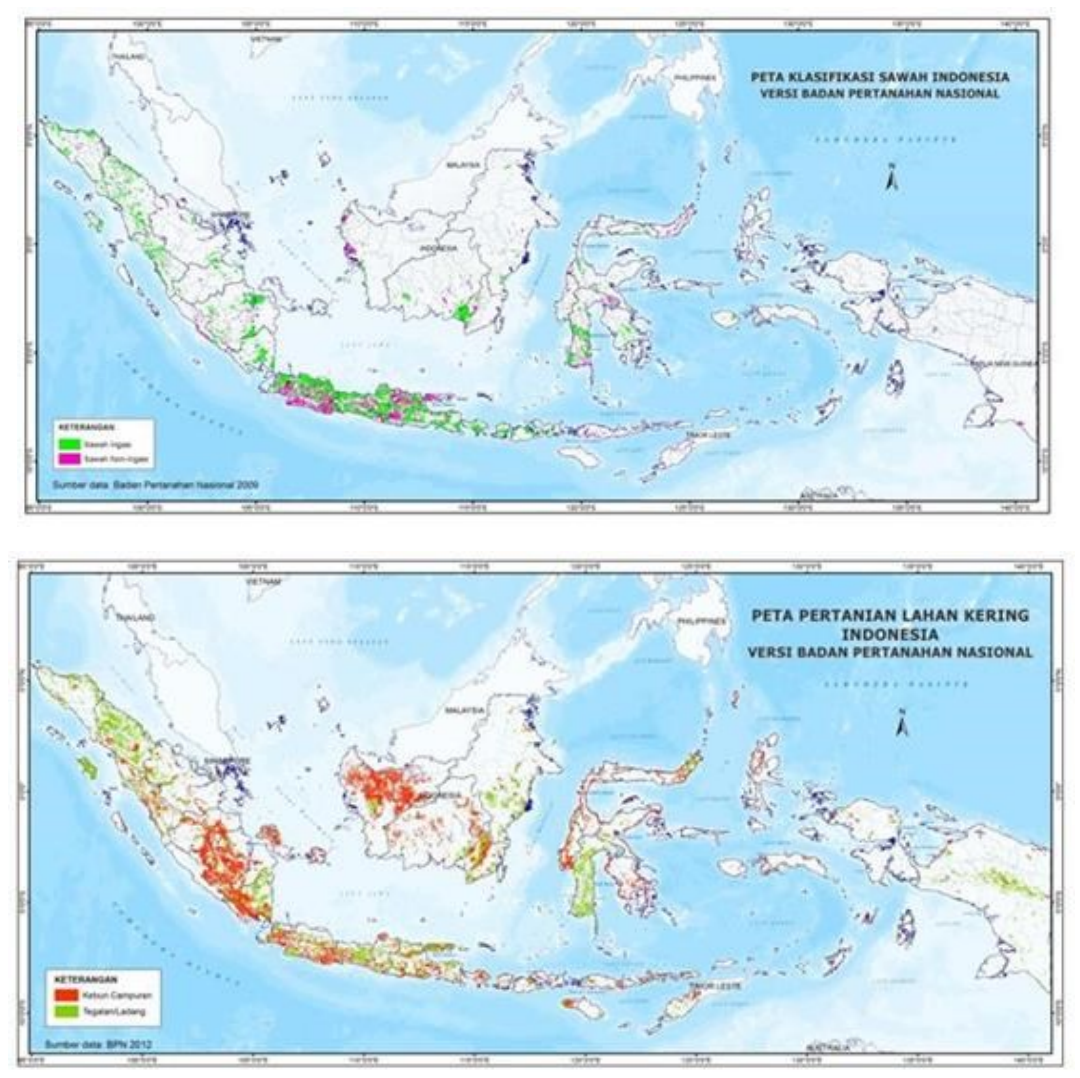

Gambar 1. Sebaran lahan pertanian lahan sawah dan lahan kering nasional eksisting

\section{Potensi Pemanfaatan Air dan Luas}

\section{Tambah Tanam}

Sebagai negara yang berada pada wilayah tropika dan dipengaruhi oleh iklim monsoon, Indonesia diberkahi dengan intensitas dan curah hujan yang tinggi, bahkan di beberapa wilayah mempunyai dua puncak hujan. Distribusi hujan juga tidak seragam akibat posisi Indonesia yang dibelah oleh garis equator dan berada di antara dua benua dan dua samudera. Bahkan di tempat yang kering pun hujan masih terjadi meskipun bersifat erratik, curah hujan tinggi dalam selang waktu yang relatif singkat.

Namun demikian saat ini air hujan belum dimanfaatkan secara optimal untuk mendukung produksi komoditas pertanian.
Seyogyanya air hujan yang jatuh dan mengalir di sungai-sungai dapat dialirkan ke lahan pertanian, terutama di wilayah bergelombang hingga berbukit dengan menerapkan konsep panen air bertingkat (cascade water harvesting) (Gambar 2).

Pada daerah berbukit sungai-sungai kecil atau parit bisa dibendung dan airnya di alirkan ke lahan-lahan pertanian hortikultura (kentang, kubis, wortel, dll). Pada daerah bergelombang, air permukaan baik dari sungai maupun dari hujan dapat ditampung di embung-embung untuk mengairi lahan pertanian palawija (jagung, kedelai, dan aneka umbi dan kacang lainnya). Pada daerah datar, embung dan long storage dibangun guna menampung air saat musim hujan serta menggunakannya 
untuk mengairi palawija dan padi saat musim kemarau. Dengan cara ini, air hujan dapat dipanen, didaur ulang dan produk pertanian (sebagai sumber karbohidrat, protein, lemak, dan vitamin) (BBSDLP, 2017b).

didayagunakan untuk menghasilkan aneka

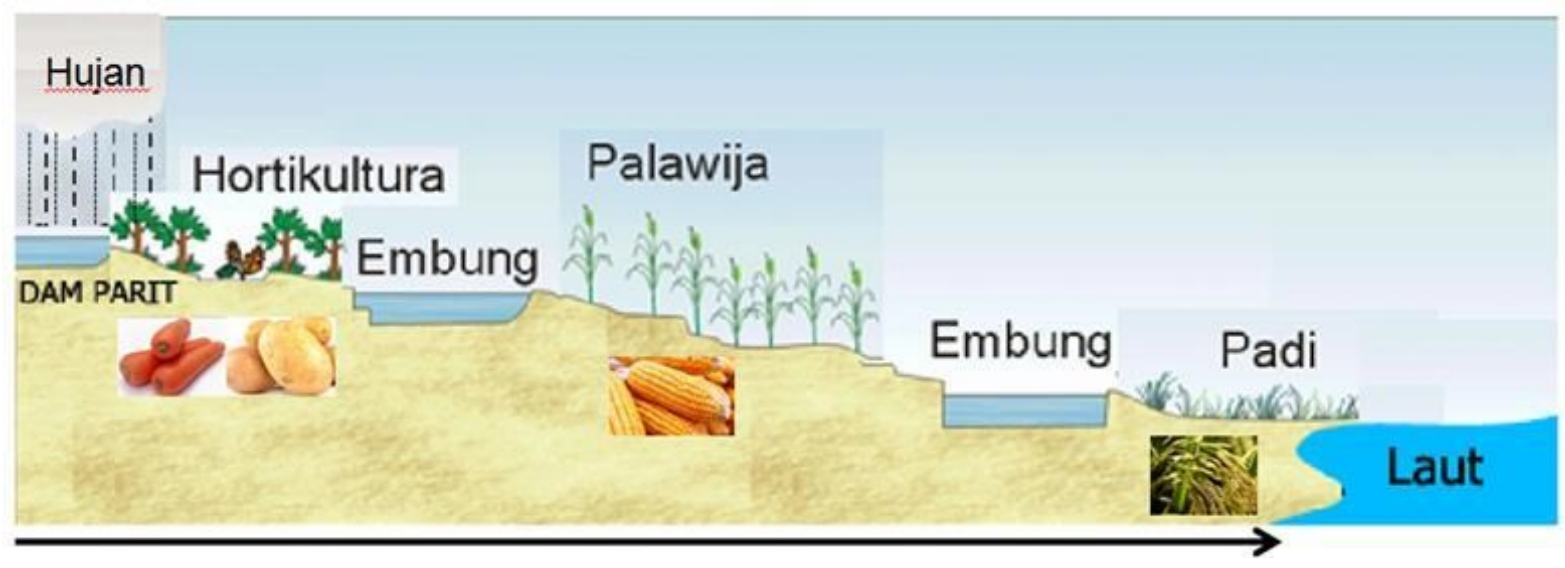

Gambar 2. Konsep panen air bertingkat untuk produksi pangan

Aliran air irigasi ke lahan-lahan pertanian bergelombang hingga berbukit dapat meningkatkan Indeks Pertanaman (IP). Sawah irigasi IP 200 dan sawah tadah hujan IP 100 dapat ditingkatkan menjadi IP 300. Lahan tegal/kebun dan lahan ladang/huma mampu ditingkatkan IP-nya dari 100 menjadi 200. Lahan tidur dapat ditingkatkan IP-nya dari 0 menjadi 200, sedangkan ladang pengembalaan luas tanamnya dapat ditingkatkan 1,5 dari luas

Tabel 2. Potensi Luas Tambah Tanam dengan Irigasi

\begin{tabular}{lccr}
\hline \multicolumn{1}{c}{ Penggunaan Lahan } & $\begin{array}{c}\text { Baku } \\
\text { (juta ha) } *\end{array}$ & $\begin{array}{c}\text { Target } \\
\text { peningkatan IP }\end{array}$ & $\begin{array}{c}\text { Potensi Luas } \\
\text { Tambah Tanam } \\
\text { (juta ha) }\end{array}$ \\
\hline Sawah Irigasi & 4,1 & $200 \rightarrow 300$ & 4,1 \\
Sawah Tadah Hujan & 4 & $100 \rightarrow 300$ & 8,0 \\
Tegal/Kebun & 12,01 & $100 \rightarrow 200$ & 12,01 \\
Ladang/Huma & 5,02 & $100 \rightarrow 200$ & 5,02 \\
Lahan Tidur & 11,68 & $000 \rightarrow 200$ & 23,36 \\
Lahan Perkebunan & 23,48 & $050 \rightarrow 150$ & 23,48 \\
Ladang Penggembalaan & 2,19 & $150 \times$ luasan & 3,29 \\
(hijauan pakan ternak) & & & 79,26 \\
Total & 62,50 & &
\end{tabular}

lahan eksisting. Dengan demikian, air irigasi ini dapat menambah luas tambah tanam sawah irigasi 4,1 juta ha, sawah tadah hujan 8,0 juta ha, tegal/kebun 12,01 juta ha, ladang/huma 5,02 ha, lahan tidur 23,36 juta ha, lahan perkebunan 23,48 juta ha, dan ladang penggembalaan (hijauan pakan ternak) 3,29 juta ha sehingga totalnya 79,26 Juta ha (Tabel 2).

Sumber: BPS (2014) 
Dari 62,5 juta hektar lahan pertanian yang tersedia, baru sekitar 4.1 juta lahan terairi irigasi, sedangkan sisanya seluas 58,4 juta hektar masih mengandalkan air hujan. Selanjutnya dari lahan non irigasi tersebut, terdapat sekitar 4 juta ha (sawah tadah hujan, lahan kering) yang prioritas untuk dikembangkan infrastruktur panen air embung kecil dan bangunan penampung air lainnya (dam parit, long storage dan pompanisasi).

\section{SITUASI TERKINI}

Kontribusi Pemanfaatan Air

Permukaan Melalui Pembangunan

Infrastruktur Panen Air untuk

Peningkatan Produksi Padi

Terdapat lima jenis infrastruktur panen air utama yaitu pemanfaatan air sungai (pompanisasi), dam parit, embung, long storage, dan sumur dangkal (BBSDLP, 2016b. Kartiwa et al, 2017).

\section{Pemanfaatan Air Sungai (Pompanisasi)}

Pemanfaatan air sungai dilakukan melalui instalasi/pemasangan pompa irigasi untuk memanfaatkan sumber air permukaan (sungai) yang memiliki elevasi/permukaan air lebih rendah dari lahan dan mendistribusikan melalui saluran irigasi secara gravitasi.

Pada Gambar 3 disajikan pemanfaatan air sungai dengan pompanisasi di Sungai Ciliuk, Desa Jaro, Kecamatan Jaro, Kabupaten Tabalong, Kalimantan Selatan.

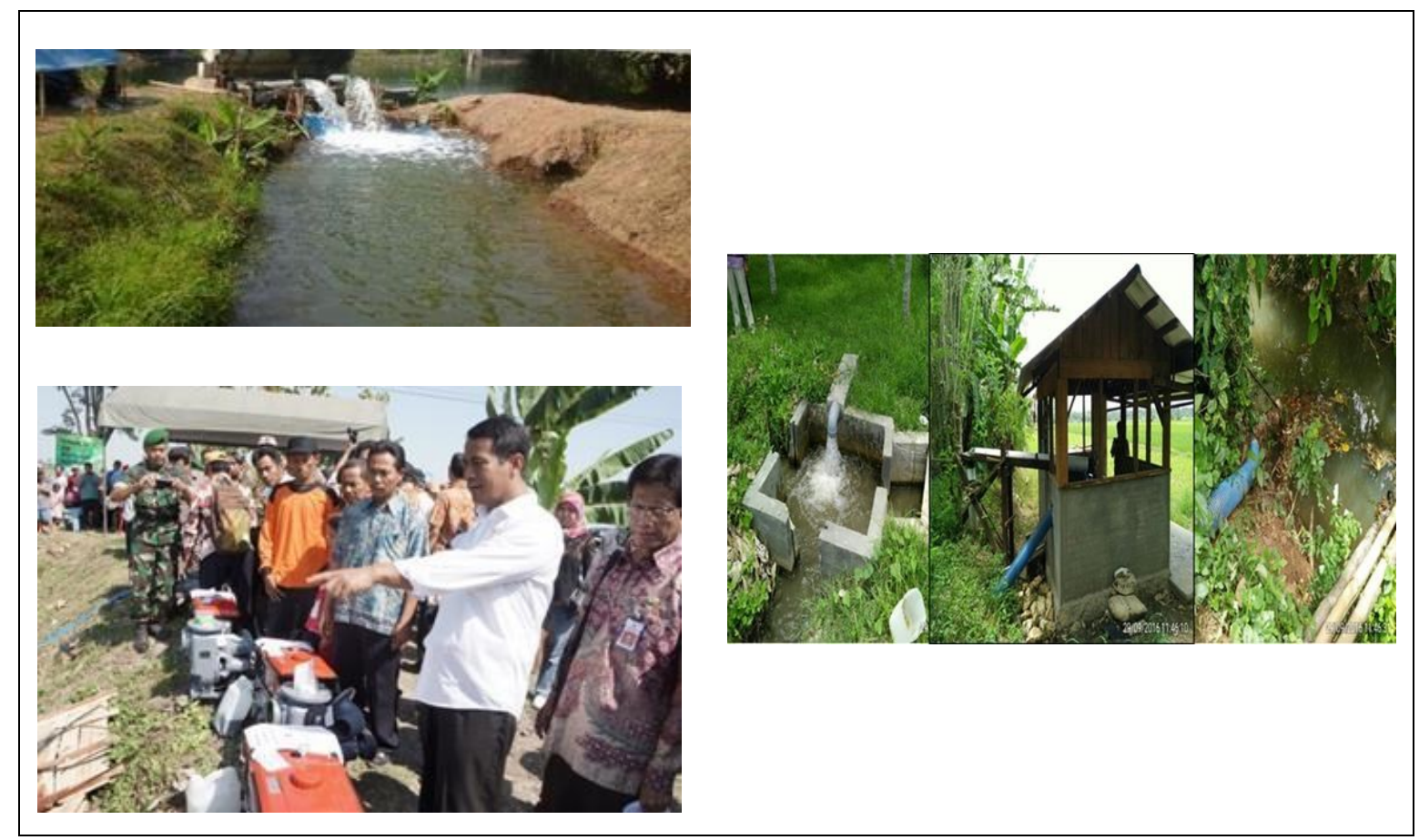

Gambar 3. Pemanfaatan air sungai dengan pompanisasi di Sungai Ciliuk, Desa Jaro, Kecamatan Jaro, Kabupaten Tabalong, Kalimantan Selatan

Pemanfaatan air sungai dengan pompanisasi di Sungai Ciliuk, Desa Jaro, Kecamatan Jaro, Kabupaten Tabalong,
Kalimantan Selatan mempunyai luas layanan 54 ha. Pompanisasi tersebut membutuhkan biaya sebesar 80 juta rupiah. 
Tambahan produksi yang diperoleh dalam 1 tahun dengan investasi tersebut sebesar 243 ton GKP setara 899 juta rupiah. Dengan pompanisasi tersebut, Desa Jaro, Kecamatan Jaro, Kabupaten Tabalong, Kalimantan Selatan mendapat tambahan IP sebesar 1,0 .

\section{Dam Parit}

Dam parit dibuat dengan membendung aliran parit atau sungai kecil serta mendistribusikan air untuk mengirigasi/mengairi lahan di sekitarnya.

Pada Gambar 4 disajikan dam parit di desa Tompobulu, Kabupaten Maros, Sulawesi Selatan.
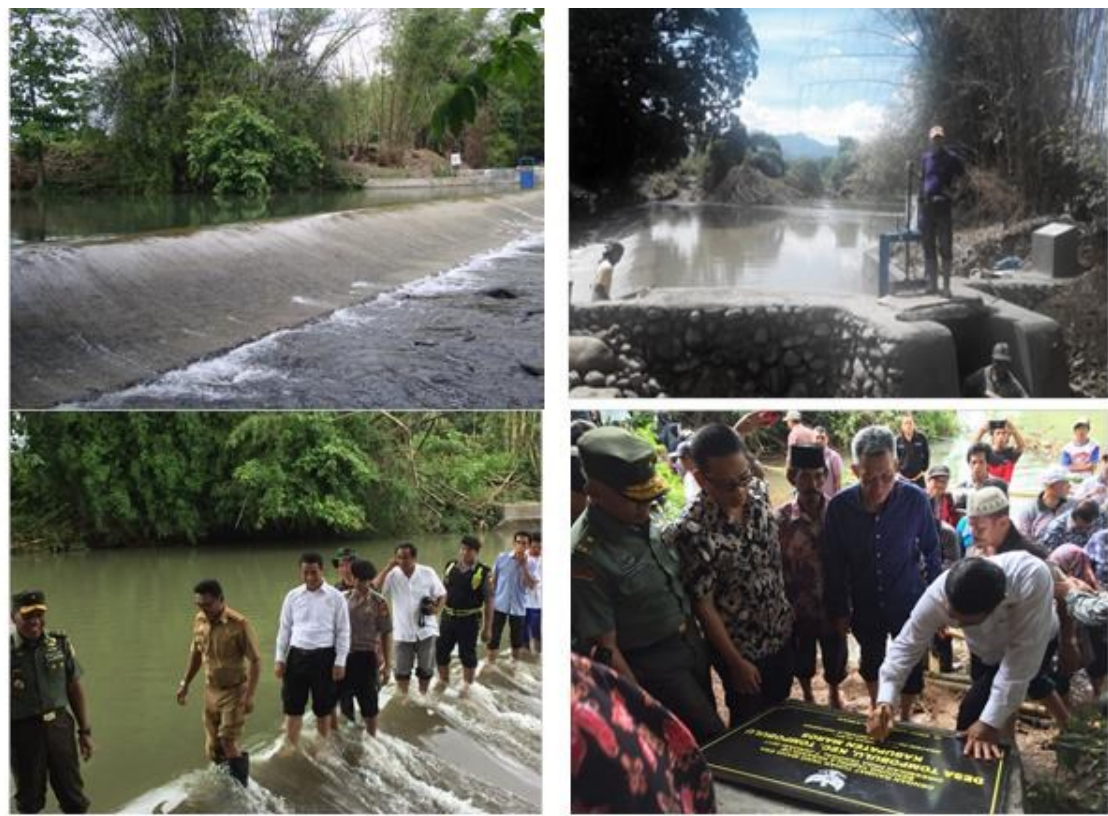

Gambar 4. Dam parit di desa Tompobulu, Kabupaten Maros, Sulawesi Selatan

Dam parit yang terdapat di desa

Tompobulu, Kecamatan Tompobulu, Kabupaten Maros memiliki lebar $60 \mathrm{~m}$ dapat memberikan layanan irigasi mencapai 75 ha. Untuk pembangunan dam parit tersebut membutuhkan biaya sebesar 150 juta rupiah. Dalam 1 tahun dengan investasi tersebut, tambahan produksi yang diperoleh sebesar 1.230 ton GKP setara 4,55 milyar rupiah. Dengan dibangunnya dam parit tersebut, desa Tompobulu, Kabupaten Maros mendapat tambahan IP sebesar 2,0 (Sosiawan et al, 2016. BBSDLP, 2017a).

\section{Embung}

Embung untuk menampung air baik yang berasal dari curah hujan, aliran permukaan maupun mata air, sebagai cadangan air untuk mengatasi kekeringan. Pada Gambar 5 disajikan embung di desa Ciomas, Kecamatan Tenjo, Kabupaten Bogor.

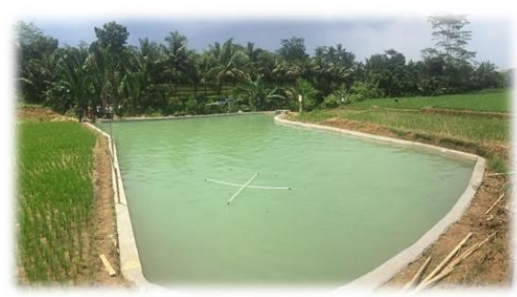

Gambar 5. Embung di desa Ciomas, Kecamatan Tenjo, Kabupaten Bogor 
Embung yang terdapat di desa Ciomas, Kecamatan Tenjo, Bogor dapat memberikan layanan irigasi pada lahan seluas 45 ha. Untuk pembangunan embung tersebut membutuhkan biaya sebesar Rp. 100 juta. Dengan investasi tersebut tambahan produksi yang diperoleh dalam 1 tahun sebesar 135 ton GKP setara Rp. 500 juta. Dengan dibangunnya embung Pada Gambar 6 disajikan long storage di desa Panyindangan Wetan, Kecamatan Sindang, Kabupaten Indramayu

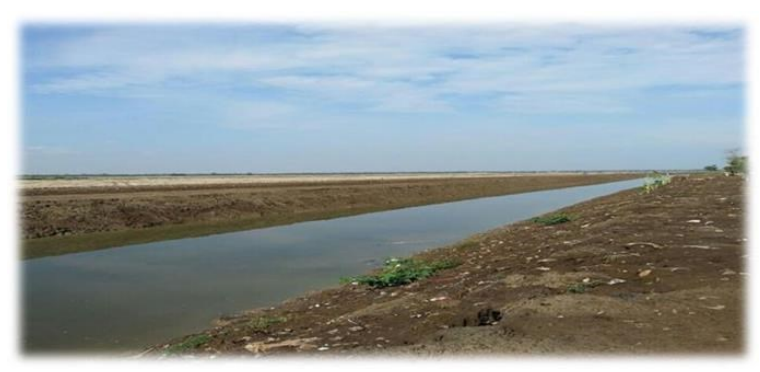

Gambar 6. Long storage di desa Panyindangan Wetan, Kecamatan Sindang, Kabupaten Indramayu

Long storage Wira yang terdapat di desa

Panyindangan Wetan, Kecamatan Sindang, Kabupaten Indramayu memiliki panjang 2.1 $\mathrm{km}$, lebar atas $18 \mathrm{~m}$, bawah $15 \mathrm{~m}$ dan dalam $3 \mathrm{~m}$ dapat memberikan layanan irigasi pada tersebut, Desa Ciomas mendapat tambahan IP sebesar 0,5.

\section{Long Storage}

Long storage berfungsi untuk menanggulangi kelebihan air (drainase) ketika musim hujan dan sebagai sumber irigasi suplementer/tambahan pada musim kemarau.

lahan seluas 900 ha. Untuk pembangunan long storage tersebut dibutuhkan biaya sebesar 875 juta rupiah. Dengan investasi tersebut tambahan produksi yang diperoleh dalam 1 tahun sebesar 2.700 ton GKP setara 9,9 milyar rupiah. Dengan dibangunnya long storage tersebut, desa Panyidangan Wetan mendapat tambahan IP sebesar 0,5.

\section{Sumur Dangkal}

Sumur dangkal merupakan sumur gali dan/atau sumur bor dengan kedalaman kurang dari $40 \mathrm{~m}$ sebagai sumber irigasi suplementer/tambahan.

Pada Gambar 7 disajikan sumur air dangkal di Kabupaten Ngawi 


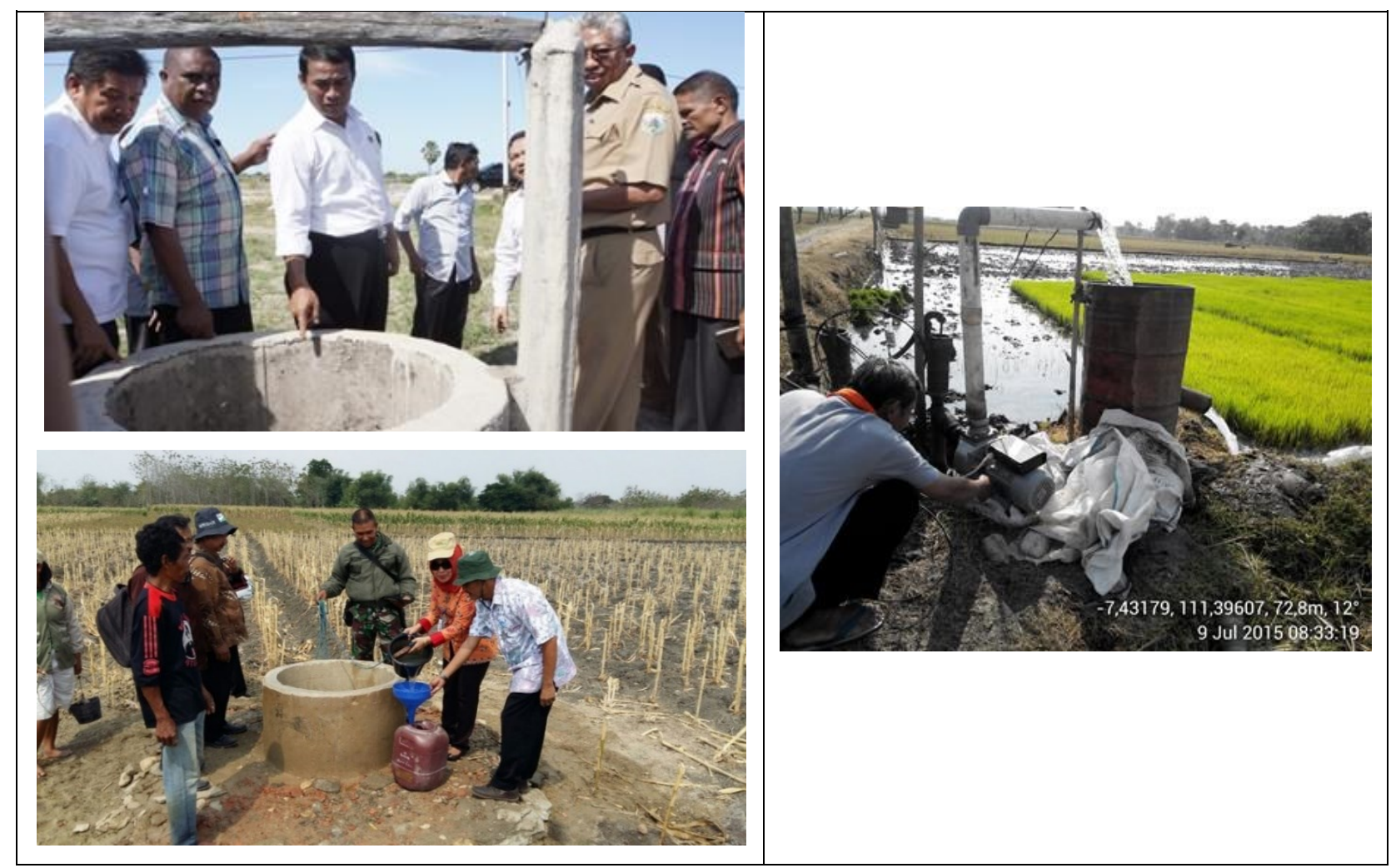

Gambar 7. Sumur air dangkal di Kabupaten Ngawi

Sumur dangkal di Kabupaten Ngawi dapat memberikan layanan irigasi pada lahan seluas 4 ha. Untuk pembangunan sumur dangkal tersebut membutuhkan biaya sebesar 8 - 10 juta rupiah. Tambahan produksi yang diperoleh dengan investasi tersebut sebesar 6 ton GKP setara 16 juta rupiah dan peningkatan IP sebesar 1,0 - 2,0.

\section{METODOLOGI}

Berikut metode yang digunakan dalam melakukan studi mengenai masalah terkait. Langkah-langkah yang dilakukan sebagai berikut:

1. Melakukan studi pendahuluan

2. Merumuskan dan mendefinisikan masalah

3. Mengumpulkan data-data jumlah pembangunan dan luas layanan embung dan bangunan air lainnya berdasarkan survei lapang dan hasil perhitungan yang dilakukan oleh Kementan dan Kemendesa PDTT yang telah di-entry dalam aplikasi SIPERDES dari Kemendesa PDT'T dan InaAgro dari Kementan.

4. Menghitung luas layanan berdasarkan rumus untuk embung dan bangunan air lainnya dengan ukuran 1 ha dapat mengairi sekitar 4 ha sawah.

5. Menghitung biaya satuan pembangunan embung dan dam parit 2,2 jt/ha luas layanan, long storage 0,97 jt/ha, pompanisasi 2,48 jt/ha (BBSDLP, 2017).

6. Menghitung biaya konstruksi dan analisis biaya satuan per luas layanan irigasi bendung berkisar 111,99-595,63 
jt/ha luas layanan (Kemen PUPR. 2017).

7. Membandingkan biaya investasi, luas layanan dan keuntungan pembangunan embung dan bending.

\section{ANALISIS DAN ALTERNATIF SOLUSI/PENANGANAN}

Keuntungan Pembangunan Infrastruktur Panen Air di Lahan 4 Juta Ha untuk Tanaman Pangan dan Hortikultura

Mulai tahun 2017, Kemendesa, PDT dan Transmigrasi bekerja sama dengan
Kementan telah membangun embung, dam parit, long storage, pompanisasi, dan sumur dangkal di Pulau Sumatera seluas 1.206.476 ha. Di Pulau Jawa, dilakukan pembangunan infrastruktur panen air dengan luas layanan 724.334 ha, di Kalimantan 1.342.702 ha, di Sulawesi 608.872 ha, di Bali dan Nusa Tenggara 117.876 ha, di Maluku dan Maluku Utara 24.216 ha dan di Papua 28.681 ha (Tabel 3).

Tabel 3. Sasaran luas layanan (ha) pembangunan infrastruktur panen air 2017 per pulau

\begin{tabular}{llrrrrrr}
\hline No & Pulau & $\begin{array}{c}\text { Dam } \\
\text { Parit }\end{array}$ & Embung & $\begin{array}{c}\text { Long } \\
\text { Storage }\end{array}$ & $\begin{array}{c}\text { Pemanfaatan } \\
\text { Sungai } \\
\text { (Pompa) }\end{array}$ & $\begin{array}{c}\text { Sumur } \\
\text { Dangkal }\end{array}$ & Jumlah \\
\hline 1 & Sumatera & 312.533 & 218.327 & 13.500 & 655.561 & 6.555 & 1.206 .476 \\
2 & Jawa & 75.595 & 130.695 & 29.044 & 486.012 & 2.989 & 724.334 \\
3 & Kalimantan & 132.866 & 282.167 & 13.230 & 912.053 & 2.386 & 1.342 .702 \\
4 & Sulawesi & 68.180 & 87.549 & 19.175 & 428.537 & 5.431 & 608.872 \\
5 & Bali dan Nusa & 15.576 & 30.778 & 8.847 & 58.558 & 4.117 & 117.876 \\
& Tenggara & & & & & & \\
6 & Maluku dan & 5.656 & 3.999 & 4.948 & 8.384 & 1.229 & 24.216 \\
& Maluku Utara & & & & & & \\
7 & Papua & 1.663 & 5.631 & 2.295 & 17.460 & 1.632 & 28.681 \\
& Jumlah & 612.068 & 759.147 & 91.039 & 2.566 .565 & 24.339 & 4.053 .157 \\
\hline
\end{tabular}

Sumber: BBSDLP, Balitbangtan, Kementan (2017b, 2017c)

Pembangunan embung kecil dan bangunan penampung air lainnya untuk tanaman padi sangat bermanfaat dan menguntungkan karena tidak membutuhkan investasi besar. Pembangunan infrastruktur panen air ini dengan layanan seluas 4 juta ha membutuhkan biaya investasi sekitar Rp 22,6 T. Berdasarkan asumsi produktivitas padi sebesar 4 ton/ha, harga gabah $\mathrm{Rp}$ 3.700/kg GKG, IP 200, maka akan diperoleh keuntungan kotor Rp 81,7 T, sehingga pendapatan bersih mencapai Rp. 59,1 T (Tabel 4). 
Tabel 4. Keuntungan pembangunan embung kecil dan bangunan penampung air lainnya untuk

\begin{tabular}{|c|c|c|c|c|c|c|}
\hline $\begin{array}{c}\text { Jenis } \\
\text { Bangunan } \\
\text { Air }\end{array}$ & $\begin{array}{c}\text { Sasaran } \\
\text { (ha) }\end{array}$ & $\begin{array}{c}\text { Jumlah } \\
\text { Unit }\end{array}$ & $\begin{array}{l}\text { Harga } \\
\text { Satuan } \\
\text { Rp/ha) }\end{array}$ & $\begin{array}{l}\text { Investasi } \\
\text { (juta Rp) }\end{array}$ & $\begin{array}{c}\text { Pendapatan } \\
\text { Kotor } \\
\text { (juta } \mathrm{Rp} \text { ) }\end{array}$ & $\begin{array}{c}\text { Keuntungan } \\
\text { (juta Rp) }\end{array}$ \\
\hline Dam Parit & 612.068 & 8.781 & 4.500 .000 & 2.754 .306 & 12.339 .289 & 9.584 .983 \\
\hline Embung & 24.339 & 1.018 & 4.000 .000 & 97.354 & 490.666 & 393.312 \\
\hline Long Storage & 91.039 & 5.832 & 4.000 .000 & 364.154 & 1.835 .338 & 1.471 .184 \\
\hline $\begin{array}{l}\text { Pemanfaatan } \\
\text { Air Sungai }\end{array}$ & 2.566 .565 & 170.483 & 5.950 .000 & 15.271 .064 & 51.741 .957 & 36.470 .894 \\
\hline $\begin{array}{l}\text { Sumur } \\
\text { Dangkal }\end{array}$ & 759.147 & 75.328 & 5.400 .000 & 4.099 .391 & 15.304 .394 & 11.205 .003 \\
\hline Jumlah & 4.053 .157 & 261.442 & & 22.586 .269 & 81.711 .645 & 59.125 .375 \\
\hline
\end{tabular}

Sumber: BBSDLP, Balitbangtan, Kementan (2017b, 2017c)

Berdasarkan asumsi produktivitas jagung sebesar 5 ton/ha, harga Rp 3.600/kg pipilan kering, maka akan diperoleh keuntungan kotor Rp 72,96 T, sehingga pendapatan bersih mencapai Rp. 50,37 T
(Tabel 5). Demikian pula manfaatnya untuk bawang merah akan menghasilkan penerimaan kotor sebesar Rp 324,25 T sehingga pendapatan bersih mencapai Rp. 301,67 T (Tabel 6).

Tabel 5. Keuntungan pembangunan embung kecil dan bangunan penampung air lainnya untuk tanaman jagung

\begin{tabular}{lrrrrrr}
\hline \multicolumn{1}{c}{$\begin{array}{c}\text { Jenis } \\
\text { Bangunan Air }\end{array}$} & \multicolumn{1}{c}{$\begin{array}{c}\text { Sasaran } \\
\text { (ha) }\end{array}$} & \multicolumn{1}{c}{$\begin{array}{c}\text { Jumlah } \\
\text { (Unit) }\end{array}$} & $\begin{array}{c}\text { Harga } \\
\text { Satuan } \\
\text { (Rp/ha) }\end{array}$ & $\begin{array}{c}\text { Investasi } \\
\text { (juta Rp) }\end{array}$ & $\begin{array}{c}\text { Penerimaan } \\
\text { Kotor } \\
\text { (juta Rp) }\end{array}$ & $\begin{array}{c}\text { Keuntungan } \\
\text { (juta Rp) }\end{array}$ \\
Dam Parit & 612.068 & 8.781 & 4.500 .000 & 2.754 .306 & 11.017 .224 & 8.262 .918 \\
Embung & 24.339 & 1.018 & 4.000 .000 & 97.356 & 438.102 & 340.746 \\
$\begin{array}{l}\text { Long Storage } \\
\text { Pemanfaatan }\end{array}$ & 91.039 & 5.832 & 4.000 .000 & 364.156 & 1.638 .702 & 1.274 .546 \\
Air Sungai & 2.566 .565 & 170.483 & 5.950 .000 & 15.271 .062 & 46.198 .170 & 30.927 .108 \\
Sumur & 759.147 & 75.328 & 5.400 .000 & 4.099 .394 & 13.664 .646 & 9.565 .252 \\
$\begin{array}{l}\text { Dangkal } \\
\text { Jumlah }\end{array}$ & 4.053 .157 & 261.442 & & 22.586 .274 & 72.956 .844 & 50.370 .570 \\
\hline
\end{tabular}

Sumber: BBSDLP, Balitbangtan, Kementan (2017b, 2017c)

Tabel 6. Keuntungan pembangunan embung kecil dan bangunan penampung air lainnya untuk tanaman bawang merah

\begin{tabular}{lrrlrrr}
\hline $\begin{array}{l}\text { Jenis Bangunan } \\
\text { Air }\end{array}$ & \multicolumn{1}{c}{$\begin{array}{c}\text { Sasaran } \\
\text { (ha) }\end{array}$} & $\begin{array}{c}\text { Jumlah } \\
\text { (Unit) }\end{array}$ & $\begin{array}{l}\text { Harga } \\
\text { Satuan } \\
\text { (Rp/ha) }\end{array}$ & $\begin{array}{c}\text { Investasi } \\
\text { (juta Rp) }\end{array}$ & $\begin{array}{c}\text { Penerimaan } \\
\text { Kotor } \\
\text { (juta Rp) }\end{array}$ & \multicolumn{1}{c}{$\begin{array}{c}\text { Manfaat } \\
\text { (juta Rp) }\end{array}$} \\
Dam Parit & 612.068 & 8.781 & 4.500 .000 & 2.754 .306 & 48.965 .440 & 46.211 .134 \\
Embung & 24.339 & 1.018 & 4.000 .000 & 97.356 & 1.947 .120 & 1.849 .764 \\
Long Storage & 91.039 & 5.832 & 4.000 .000 & 364.156 & 7.283 .120 & 6.918 .964 \\
Pemanfaatan & 2.566 .565 & 170.483 & 5.950 .000 & 15.271 .062 & 205.325 .200 & 190.054 .138 \\
Air Sungai & & & & & & \\
Sumur Dangkal & 759.147 & 75.328 & 5.400 .000 & 4.099 .394 & 60.731 .760 & 56.632 .366 \\
Jumlah & 4.053 .157 & 261.442 & & 22.586 .274 & 324.252 .640 & 301.666 .366 \\
\hline
\end{tabular}


Sumber: BBSDLP, Balitbangtan, Kementan (2017b, 2017c)

\section{Keuntungan Pembangunan Infrastruktur Panen Air (Embung Kecil dan Bangunan Air Lainnya dibandingkan Bendung)}

Infrastruktur panen air embung kecil dan bangunan penampung air lainnya memiliki beberapa keunggulan dibandingkan dengan infrastruktur panen air bendung. Indikator keunggulan irigasi meliputi: waktu menghasilkan yang cepat, pemeliharaan murah, melibatkan partisipasi masyarakat, biaya investasi rendah, tidak memiliki risiko sosial tinggi, ramah lingkungan karena menekankan aspek konservasi air dan rendah emisi GRK, serta terdapat co-benefit tinggi (Tabel 7).

Tabel 7. Perbandingan keunggulan dan kelemahan jenis infrastruktur panen air

\begin{tabular}{clll}
\hline No. & \multicolumn{1}{c}{ Indikator Keunggulan } & \multicolumn{1}{c}{ Bendung } & \multicolumn{1}{c}{$\begin{array}{c}\text { Embung kecil dan } \\
\text { bangunan air lainnya }\end{array}$} \\
\hline 1 & Waktu menghasilkan (quick yield) & Lama (30 tahun) & Cepat (6 bulan) \\
2 & Pemeliharaan & Mahal & Murah \\
3 & Partisipasi masyarakat (kontrol & Rendah & Gotong royong \\
& sosial) & Mahal & Swadaya \\
4 & Tenaga kerja & Tinggi & Rendah \\
5 & Biaya investasi & Risiko tinggi & Risiko rendah \\
6 & Masalah sosial & Tidak Ramah (kurang & Ramah (baik) \\
7 & Lingkungan (konservasi air) & baik) & Tinggi \\
& & Rendah & Rendah \\
\hline
\end{tabular}

BBSDLP, Balitbangtan, Kementan (2017b)

Beberapa infrastruktur panen air embung kecil dan bangunan penampung air lainnya yang dibangun oleh kementerian pertanian di beberapa kabupaten dalam beberapa tahun terakhir ini, memerlukan biaya investasi berkisar antara Rp. 80 juta hingga Rp. 875 juta, dengan variasi luas layanan irigasi antara 45 hingga 900 ha. Berdasarkan kedua informasi tersebut, biaya satuan pembangunan embung kecil dan bangunan penampung air lainnya berkisar antara Rp. 0,97 jt/ha hingga Rp. 2,48 jt/ha dengan rata-rata Rp. 1.21 jt/ha (Tabel 8).
Sementara itu menurut data yang diperoleh dari Kementerian PUPR, sebanyak 65 bendung yang telah dibangun di seluruh wilayah Indonesia pada beberapa tahun terakhir memerlukan total anggaran hingga 73,31 T, dengan total luas layanan irigasi mencapai 468,382 ha, sehingga ratarata biaya satuan mencapai Rp. 156,52 jt/ha (Tabel 9). Tabel 8 dan 9 menunjukkan bahwa biaya satuan embung kecil dan bangunan penampung air lainnya jauh lebih murah dibandingkan dengan biaya satuan bendung. 
Tabel 8. Rekapitulasi biaya konstruksi dan biaya satuan per luas layanan irigasi embung kecil dan bangunan penampung air lainnya

\begin{tabular}{llccc}
\hline \multicolumn{1}{c}{ Bangunan Air } & \multicolumn{1}{c}{ Lokasi } & $\begin{array}{c}\text { Biaya Kontruksi } \\
\text { (jt Rp) }\end{array}$ & $\begin{array}{c}\text { Luas layanan } \\
\text { (ha) }\end{array}$ & $\begin{array}{c}\text { Biaya Satuan } \\
\text { (jt Rp/ha) }\end{array}$ \\
\hline Dam parit & Maros & 150 & 75 & 2,00 \\
Dam parit & Bima & 100 & 45 & 2,20 \\
Embung & Bogor & 100 & 45 & 2,20 \\
Long storage & Indramayu & 875 & 900 & 0,97 \\
Pompanisasi & Tabalong & 80 & 54 & 2,48 \\
Dam parit & Jepara & 100 & 45 & 2,20 \\
Total & 1.405 & 1.164 & 1,21 \\
Rata-rata Biaya Satuan & & & \\
\hline
\end{tabular}

Sumber: BBSDLP, Balitbangtan, Kementan (2017b)

Tabel 9. Rekapitulasi Biaya Konstruksi dan Analisis Biaya Satuan per Luas Layanan Irigasi Bendung (Kemen PUPR)

\begin{tabular}{clcrrr}
\hline No. & Pulau & $\begin{array}{c}\text { Jumlah } \\
\text { Bendung }\end{array}$ & $\begin{array}{c}\text { Biaya Kontruksi } \\
\text { (T Rp) }\end{array}$ & $\begin{array}{c}\text { Layanan Irigasi } \\
\text { (ha) }\end{array}$ & $\begin{array}{c}\text { Biaya Satuan } \\
\text { (jt Rp/ha) }\end{array}$ \\
1 & Sumatera & 11 & 12,94 & 88.002 & 146,99 \\
2 & Jawa & 24 & 25,27 & 226.375 & 111,64 \\
3 & Kalimantan & 5 & 8,45 & 33.472 & 252,58 \\
4 & Bali & 3 & 2,11 & 7.586 & 278,66 \\
5 & NTB & 4 & 2,10 & 12.134 & 173,37 \\
6 & NTT & 7 & 5,55 & 14.696 & 377,96 \\
7 & Sulawesi & 9 & 10,45 & 75.217 & 138,93 \\
8 & Maluku & 1 & 1,66 & 2.900 & 572,59 \\
9 & Papua & 1 & 4,77 & 8.000 & 595,63 \\
Total & Riata-rata Biava Satuan & 65 & 73,31 & 468.382 & 156,52 \\
\hline
\end{tabular}

Sumber: Kemen PUPR (2017)

Perbandingan beberapa parameter

infrastruktur panen air menunjukkan bahwa dengan biaya investasi sebesar Rp. 1,41 M, dapat dibangun embung kecil dan bangunan penampung air lainnya dengan total luas layanan mencapai 352,5 ha, sedangkan dengan biaya investasi yang sama, pembangunan bendung hanya mampu melayani lahan seluas 9 ha. Demikian pula dengan biaya investasi sebesar Rp. 73,3 T, dapat dibangun embung kecil dan bangunan penampung air lainnya dengan total luas layanan mencapai 18,4 juta ha, sedangkan dengan biaya investasi yang sama, pembangunan bendung hanya mampu melayani lahan seluas 468,4 ribu ha (Tabel $10)$. 
Tabel 10. Perbandingan beberapa parameter embung kecil dan bangunan penampung air Lainnya VS Bendung

\begin{tabular}{llcc}
\hline No & \multicolumn{1}{c}{ Parameter } & \multicolumn{1}{c}{$\begin{array}{c}\text { Embung Kecil dan } \\
\text { Bangunan Penampung Air } \\
\text { Lainnya }\end{array}$} & Bendung \\
& Rp. 1,41 Milyar & Rp. 73.310 Milyar \\
1 & Biaya Kontruksi Total & 352,5 ha & 46.382 ha \\
2 & Luas Layanan Irigasi Total & Rp. 4 juta/ha & Rp. 157 juta ha \\
3 & Rata-rata Biaya Satuan & 353 ha & 9 ha \\
4 & $\begin{array}{l}\text { Luas Layanan Irigasi Pada Biaya Rp, } \\
\text { 1,41 M }\end{array}$ & & 468.387 ha \\
5 & $\begin{array}{l}\text { Luas Layanan Irigasi Pada Biaya Rp, } \\
73,310 \mathrm{M}\end{array}$ & 18.372 .373 ha & \\
\hline
\end{tabular}

\section{REFERENSI}

BAPPENAS. 2010. Indonesia Climate Change Sectoral Roadmap (ICCSR): Water Resources Sector Report. National Development Planning Agency, Republic of Indonesia.

BBSDLP. 2016a. Meningkatan Kesejahteraan Petani Melalui Swasembada Pangan (Produktivitas Lahan Kering 4 Juta Ha). Bahan Rapat Koordinasi, Jakarta, 25 Oktober 2016

BBSDLP. 2016b. Pengembangan Inovasi Teknologi Tata Kelola Air Untuk Peningkatan IP Dan Produktivitas Pangan. Raker Balitbangtan Bogor, 27-29 November 2016

BBSDLP. 2017a. Implementasi Embung dan Bangunan Air 2017. Bahan Rapat Koordinasi, Bogor, 6 April, 2017

BBSDLP. 2017b. Reorientasi Kebijakan Pengembangan Infrastruktur Irigasi Nasional. Bahan Rapat Koordinasi, Bogor, 4 Mei 2017

$\begin{array}{rrr}\text { BBSDLP. 2017c. } & \text { Embung } & \text { Solusi } \\ \text { Peningkatan } & \text { Produksi } & \text { Pangan }\end{array}$

Nasional. Bahan Pembahasan di Bappenas, 12 Mei 2017

Kartiwa, B., Rejekiningrum, P., Sosiawan, H., Sutrisno, N. Hamdani, A., Harmanto, Nursyamsi. D. 2017. Petunjuk Teknis Implementasi Infrastruktur Panen Air. Badan Litbang Pertanian. 13 hal.

Kementerian PUPR. 2017. Pusat Bendungan. Bahan Rapat Koordinasi, 7 Februari 2017.

Puslitbang Air. 2016. Panduan Perencanaan Adaptasi Perubahan Iklim Untuk Sistem Penyediaan Air Minum. Indonesia Urban Water Sanitation And Hygiene, Mayapada Tower 10th Fl Jalan Jendral Sudirman Kav. 28 Jakarta 12920 Indonesia. 52 hal.

Sosiawan, H., Sudarman, K., Kartiwa, B. 2016. Pendalaman Identifikasi Wilayah Potensial Pengembangan IP-300 Berdasarkan Peta Potensi Pengembangan Kawasan Pertanian PJKU untuk Penyusunan Strategi Optimalisasi Pemanfaatannya. Laporan Akhir Kegiatan on Top Perubahan Iklim. Balai Penelitian Agroklimat dan Hidrologi, Badan Litbang Pertanian Bogor. Tidak Dipublikasikan 